\title{
IMPLEMENTASI ALGORITMA DIVIDE AND CONQUER PADA APLIKASI BELAJAR ILMU TAJWID
}

\author{
Dais Suryani ${ }^{1}$, Mohamad Irfan ${ }^{2}$, Wisnu Uriawan ${ }^{3}$, Wildan Budiawan $Z^{4}$ \\ ${ }_{1,2,3,4}$ Jurusan Teknik Informatika, Fakultas Sains dan Teknologi \\ Universitas Islam Negeri Sunan Gunung Djati Bandung \\ Jl. A.H. Nasution 105, Bandung 40614 Indonesia \\ ${ }^{1}$ suryanidais@gmail.com, ${ }^{2}$ irfan.bahaf@uinsgd.arc.id, \\ ${ }^{3}$ wirsnu_u@uinsgd.ac.id, ${ }^{4}$ wildan.budiawan.z@uinsgd.ac.id
}

Abstrak- Seorang muslim harus bisa membaca ayatayat Al-Quran dengan baik sesuai yang diajarkan oleh Rasulullah saw. Membaca Al-Quran sesuai ilmu tajwid hukumnya wajib bagi setiap orang, tidak bisa diwakili oleh orang lain. Aplikasi ilmu tajwid yang dibangun bersifat mobile, sehingga user dapat mempelajari tajwid dimana saja dan kapan saja. Selain menambah wawasan tentang tajwid, user dapat membaca AlQuran secara fasih sesuai hukum tajwid karena aplikasi yang bersifat mobile ini mendukung pembelajaran menggunakan teks dan suara. Selain itu user dapat juga mengasah kemampuannya tentang ilmu tajwid melalui soal-soal yang ada dalam aplikasi. Aplikasi Belajar Ilmu Tajwid menerapkan salah satu algoritma yaitu divide and conquer. Algoritma divide and conquer diimplementasikan pada pencarian jawaban pada soal yang ada pada menu latihan. Algoritma divide and conquer mempunyai cara kerja membagi masalah menjadi beberapa sub masalah sehingga dihasilkan solusi akhir dari masalah awal. Algoritma divide and conquer mempunyai kompleksitas yang cukup cepat yaitu 2,86272753, dibandingkan dengan algoritma Brute Force yang memiliki kompleksitas lebih tinggi daripada algoritma divide and conquer yaitu 6.

Kata Kunci : Al-Quran, tajwid, mobile,divide and conquer, Brute Force, kompleksitas

\section{PENDAHULUAN}

\section{A. Latar Belakang}

Seorang muslim harus bisa membaca ayat-ayat AlQuran dengan baik sesuai yang diajarkan oleh Rasulullah saw. Membaca Al-Quran sesuai ilmu tajwid hukumnya wajib bagi setiap orang, tidak bisa diwakili oleh orang lain. Apabila seseorang membaca Al-Quran dengan tidak memakai tajwid, hukumnya berdosa karena sesungguhnya Allah SWT menurunkan Al-Quran berikut tajwidnya.[3]

Pembelajaran tajwid sudah diajarkan sejak dini di bangku sekolah dan dalam jangka waktu yang lama. Akan tetapi, hanya sedikit masyarakat muslim yang benar-benar memahami ilmu tajwid. Meskipun minat belajar ilmu tajwid masih ada, namun banyak dari masyarakat yang sibuk dengan aktivitasnya sehingga tidak bisa membagi waktu untuk belajar ilmu tajwid, maka masyarakat memilih belajar ilmu tajwid di rumah. Namun media pembelajaran yang tersedia di rumah memiliki kekurangan, seperti buku yang penyajiannya berupa tulisan sehingga susah dipahami makna bunyi dan panjang pendek dari suatu bacaan tajwid.

Dengan perkembangan teknologi android ini, maka terbuka peluang yang sangat besar bagi programmer untuk terlibat mengembangkan aplikasi android. Salah satu aplikasi yang dapat diciptakan dari teknologi android ialah aplikasi pembelajaran ilmu tajwid. Teknologi yang dimiliki android dapat mendukung proses pembelajaran ilmu tajwid secara praktis karena sifatnya mobile serta dapat mendukung pembelajaran menggunakan teks dan suara.

Android adalah sebuah sistem operasi untuk perangkat mobile berbasis linux yang mencakup sistem operasi, middleware dan aplikasi.[5] Pertumbuhan pasar perangkat berbasis android mendorong pertumbuhan pengembangan aplikasi berbasis android. Berdasarkan informasi dari situs resmi (www.android.com), setiap hari terdapat lebih dari satu juta perangkat android diaktifkan dan diperkirakan akan terus meningkat. [6]

Untuk membantu atau mempermudah pembuatan aplikasi ilmu tajwid ini, maka digunakan suatu algoritma untuk menyelaesaikan masalah. Algoritma yang digunakan dalam pembuatan aplikasi ini ialah algoritma divide and conquer. Divide and Conquer adalah varian dari beberapa strategi pemrograman yang digunakan untuk memecahkan masalah yang besar menjadi sub masalah yang lebih kecil.[2]

Berdasarkan latar belakang di atas, maka akan dibangun aplikasi yang berjudul "Implementasi Algoritma Divide and Conquer Pada Aplikasi Belajar Ilmu Tajwid".

\section{B. Rumusan Masalah}

Berdasarkan latar belakang di atas, maka dapat dirumuskan beberapa masalah diantaranya:

a. Bagaimana mengimplementasikan algoritma divide and conquer pada Aplikasi Belajar Ilmu Tajwid?

b. Bagaimana user belajar ilmu tajwid dan membaca AlQuran dengan fasih sesuai dengan ilmu tajwid? 


\section{Tujuan Penelitian}

Dengan permasalahan yang dipaparkan dalam rumusan masalah, diharapkan dapat mencapai beberapa tujuan sebagai berikut:

a. Mengimplementasikan Algoritma divide and conquer pada aplikasi belajar ilmu tajwid.

b. Membantu user belajar ilmu tajwid dan membaca AlQuran dengan fasih sesuai dengan ilmu tajwid.

D. Batasan Masalah

Batasan masalah yang terdapat pada laporan ini diantaranya:

a. Aplikasi ini dirancang menggunakan model perancangan UML (Unified Modeling Language).

b. Suara qiro'at yang dipakai dalam aplikasi yaitu qiro'at dari KH Muammar ZA.

c. Teks paragraf yang terdapat pada aplikasi ilmu tajwid ialah align left text.

d. Dalam aplikasi belajar ilmu tajwid setiap hukum tajwid memiliki satu contoh hukum tajwid.

e. Soal latihan yang terdapat pada aplikasi belajar ilmu tajwid bersifat tidak random.

Aplikasi belajar ilmu tajwid ini hanya sampai tahap evaluasi terhadap user.

\section{LANDASAN TEORI \\ A. Algoritma Divide and Conquer}

Divide and Conquer secara umum terbagi dalam tiga fase, divide yakni membagimasalah kedalam sub-sub masalah yang lebih kecil,conquer yakni menyelesaikan sub-sub masalah secara rekursif, dancombine menggabungkanhasil dari penyelesian sub-sub masalah menjadi penyelesaian yang dikehendaki.[2]

Ada empat hal yang harus dipahami dalam strategi divide and conquer, yaitu:

\section{a. Branching Factor}

Branching factor dalam algoritma divide and conquer adalah jumlah dari subproblem yang akan dibagi dari sebuah problem awal. Ini adalah langkah nyata dari algoritma divide and conquer, didalam proses pembagian yang sebenarnya, jumlah dari branching factor harus 2 atau lebih, karena jika tidak problem tidak bisa dibagi.

b. Balance

Sebuah algoritma divide and conquer dikatakan balance jika problem awal dibagi menjadi sub-sub problem dengan ukuran yang sama. Yang artinya jumlah dari keseluruhan ukuran sub problem sama dengan ukuran problem awal.

\section{c. Data Dependence of Divide Function}

Algoritma divide and conquer memiliki sebuah fungsi pembagian terhadap data yang memiliki ketergantungan, artinya jika ukuran relatif dari sebuah sub problem tergantung pada proses input datanya.

\section{d. Control Parallelism or Sequentiality}

Algoritma divide and conquer dikatakan berurutan (sequential) jika sub problem dieksekusi sesuai dengan perintah program.

\section{B. Ilmu Tajwid}

Tajwid secara bahasa berasal dari kata jawwada, yujawwidu, jajwidan yang artinya membaguskan atau membuat jadi bagus. Sedangkan menurut istilah, ilmu tajwid ialah ilmu yang memberikan segala pengertian tentang huruf (haqqul harf) maupun hukum-hukum baru yang timbul setelah hak-hak huruf (mustahaqqul harf) dipenuhi, yang terdiri atas sifat-sifat huruf, hukum-hukum mad, dan lain sebagainya.[3]

Imam Jalaluddin as-Suyuthi memberikan penekanan yang hampir sama pada definisi tajwid, yaitu memberikan huruf akan hak-haknya dan tertibnya, mengembalikan huruf pada makhraj dan asal (sifat) nya serta menghaluskan pengucapan dengan cara yang sempurna tanpa berlebihlebihan, serampangan, tergesa-gesa, dan dipaksakan.[3]

C. Hukum Nun Bersukun dan Tanwin

Hukum nun bersukun atau tanwin adalah empat hukum yang muncul tatkala nun bersukun atau tanwin menghadapi huruf hijaiyah. Empat hukum tersebut ialah:

1. Izh-har halqi

2. Idgham

3. Iqlab

4. Ikhfa

D. Hukum Mim Bersukun

Hukum mim bersukun ialah tiga hukumyang muncul tatkala mim bersukun menghadapi huruf hijaiyah. Tiga hukum itu diantaranya:

1. Ikhfa Syafawi

2. Idgham Mimi

3. Izh-har Syafawi

E. Hukum Idgham

Hukum idgham ialah tiga hukum yang muncul tatkala dua huruf yang sama, sejenis atau berdekatan makhraj atau sifat-sifatnya saling berhadapan. Tiga hukum itu ialah:
1. Idgham Mutamatsilain
2. Idgham Mutajanisain
3. Idgham Mutaqaribain
F. Hukum Mim dan Nun Bertasydid 
Jika kita membaca Al-Quran kemudian menemukan huruf mim dan nun yang bertasydid, maka disana terdapat hukum Ghunnah Musyaddadah. Ghunnah menurut bahasa artinya sengau atau dengung (mendengung), musyaddadah artinya bertasydid atau memakai tasydid.

\section{G. Hukum Lam Ta'rif}

Hukum Lam Ta'rif membahas tentang alif lam ketika menghadapi huruf hijaiyah, baik yang tergolong hurufhuruf qamariyyah maupun huruf-huruf syamsiyyah. Pembicaraan seputar alif lam inilah yang menyebabkan hukum lam ta'rif dikenal pula dengan sebutan hukum alif lam. Hukum lam ta'rif terbagi atas dua bagian, yaitu:

H. Qalqalah

Qalqalah menurut bahasa ialah bergerak atau bergetar. Sedangkan menurut istilah, qalqalah ialah suara tambahan (pantulan) yang kuat dan jelas yang terjadi pada huruf yang bersukun setelah menekan pada makhraj huruf tersebut. Huruf-huruf qalqalah ada 5, yaitu Dalam ilmu tajwid, qalqalah terbagi menjadi dua, yaitu qalqalah shughra dan qalqalah kubra.

\section{Hukum Mad}

Mad menurut bahasa ialah memanjangkan dan menambah. Sedangkan menurut istilah mad ialah memanjangkan suara dengan salah satu huruf dari hurufhuruf mad (ashli). Huruf mad seperti yang dimaksudkan dalam definisi diatas ada tiga, yaitu I, و dan . Mad terbagi atas dua bagian, yaitu:

\section{Mad Ashli}

Mad Ashli dikenal pula dengan istilah mad thabi'i. Thabi'i secara bahasa artinya tabiat. Mad ashli diistilahkan pula dengan mad thabi'i karena seseorang yang mempunyai tabiat baik tidak mungkin akan mengurangi atau menambah panjang bacaan dari yang telah ditetapkan. Adapun cara membaca mad Ashli ialah dengan memanjangkan bacaan dua harakat (satu alif), baik disaat washal maupun waqaf.

\section{Mad Far'i}

Far'i secara bahasa ialah cabang. Sedangkan menurut istilah, mad far'i ialah mad yang merupakan hukum tambahan dari mad ashli (sebagai hukum asalnya), yang disebabakan oleh hamzah atau sukun. Hukum-hukum yang merupakan bagian dari mad far'i antara lain:

1. Mad Wajib Muttashil

2. Mad Jaiz Munfashil

3. Mad Lazim Harfi Musyba

4. Mad Lazim Harfi Mukhafaf

5. Mad Lazim Kalimi Mutsaqal

6. Mad Lazim Kalimi Mukhafaf

7. Mad Badal

8. Mad aridl lis Sukun

9. Mad Iwadl

10. Mad Lin

11. Mad Shilah Qashirah

12. Mad Shilah Thawilah

13. Mad Tamkin

14. Mad Farq

\section{METODE PENELITIAN}

\section{A. Pengumpulan Data}

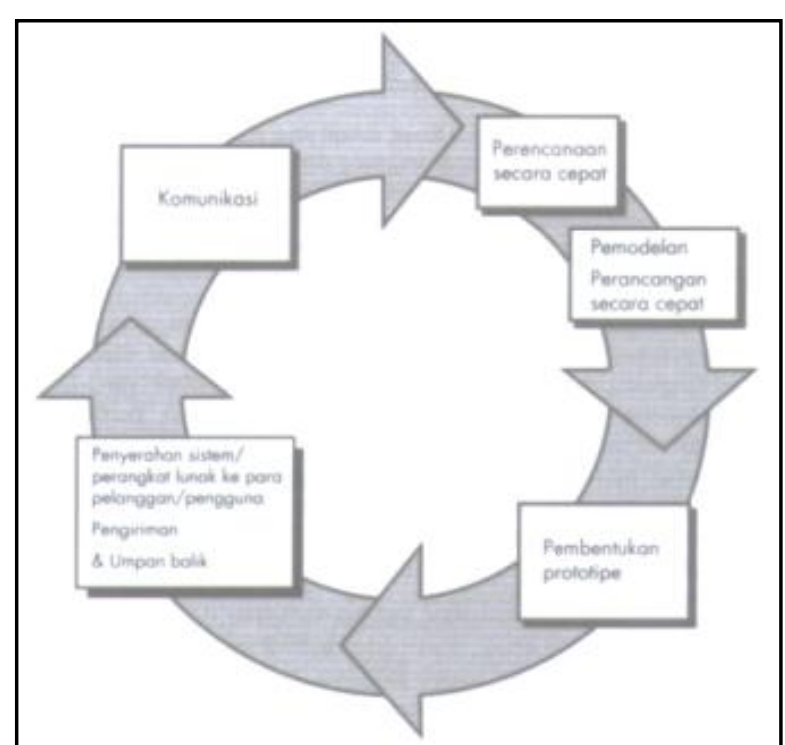

Untuk membantu pembuatan sistem ini maka dilakukan pengumpulan data dengan cara mencari bukubuku, jurnal maupun referensi dari internet.

\section{B. Pengembangan Sistem}

Adapun untuk pembuatan aplikasi menggunakan metode pengembangan perangkat lunak Prototype, karena metode ini cocok digunakan untuk sistem atau aplikasi yang dibangun mengikuti kebutuhan pengguna, metode ini sangat sesuai diterapkan dalam proses perancangan perangkat lunak yang akan dibangun yang menitikberatkan pada pendekatan aspek desain, fungsi, dan userinterface.

Gambar 1 Metode Pengembangan Perangkat Lunak Prototype [4]

Pembuatan Prototype dimulai dengan dilakukannya komunikasi antara tim pengembang perangkat lunak pada pelanggan. Tim pengembang perangkat lunak akan melakukan pertemuan-pertemuan dengan stakeholder untuk mendefinisikan sasaran keseluruhan untuk perangkat lunak yang akan dikembangkan, mengidentifikasi spesifikasi kebutuhan apa pun yang saat ini diketahui, dan menggambarkan area-area dimana definisi lebih jauh pada iterasi selanjutnya.

Iterasi pembuatan prototype direncanakan dengan cepat dan pemodelannya dilakukan dalam bentuk rancangan cepat. Suatu rancangan cepat berfokus pada representasi semua aspek perangkat lunak yang akan dilihat oleh para pengguna akhir (misalnya rancangan antarmuka pengguna [user interface] atau format tampilan). Rancangan cepat (quick design) akan memulai konstruksi pembuatan prototype.

Prototype kemudian akan diserahkan kepada para stakeholder dan kemudian mereka akan melakukan evaluasi-evaluasi tertentu terhadap prototype yang telah dibuat sebelumnya, kemudian akhirnya akan memberikan umpan balik yang akan digunakan untuk memperhalus spesifikasi kebutuhan. Iterasi akan terjadi saat prototype diperbaiki untuk memenuhi kebutuhan dari stakeholder, sementara pada saat yang sama memungkinkan kita untuk lebih memahami kebutuhan apa yang akan dikerjakan pada iterasi selanjutnya. 


\section{PEMBAHASAN}

\section{A. Use Case Diagram}

Use Case Diagram adalah deskripsi fungsi dari sebuah sistem dari perspektif pengguna. Use Case bekerja dengan cara mendeskripsikan tipikal interaksi antara user (pengguna) sebuah sistem dengan sistemnya sendiri melalaui sebuah cerita bagaimana sebuah sistem dipakai.[7]

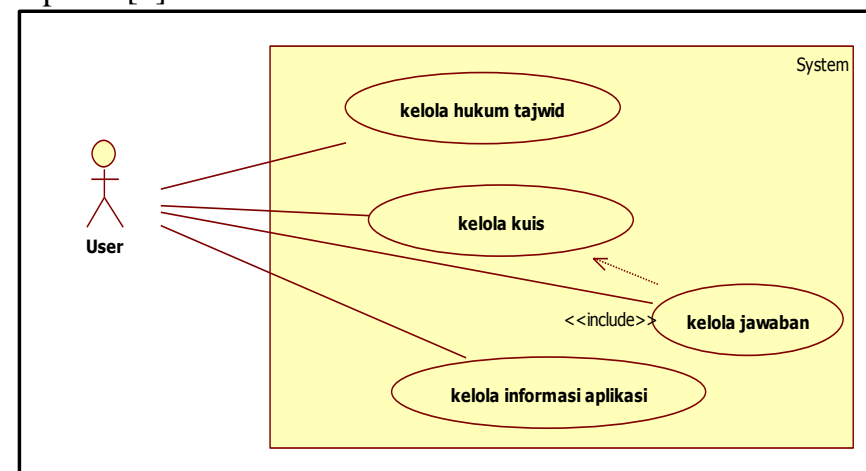

Gambar 2Use Case Diagram Belajar Ilmu Tajwid

\section{B. Class Diagram}

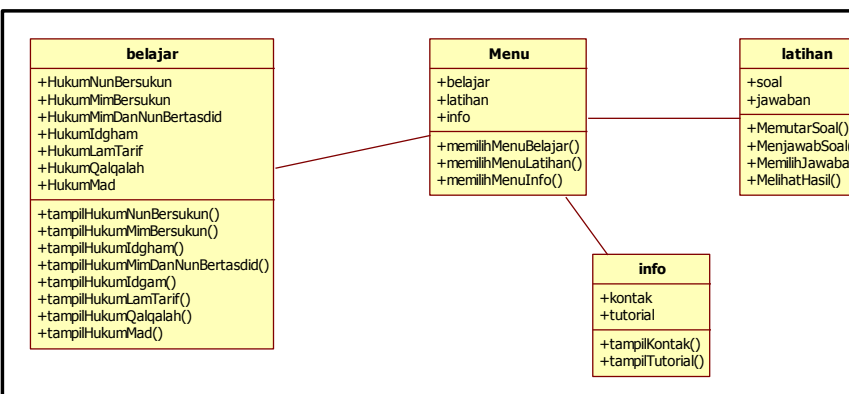

Gambar 3Class Diagram Belajar Ilmu Tajwid

Dalam perancangan sistem ini terdapat 4 class yang masing-masing memiliki fungsi yang mendukung kinerja sistem. Class-class yang terdapat dalam class diagram yaitu:

a. Class menu, merupakan class yang menjalankan fungsi tampilan menu yang menjalankan aktivitas awal dalam membuka aplikasi.

b. Class belajar, merupakan class yang memiliki fungsi menampilkan teori tajwid yang akan dibaca oleh user. Teori yang ada dalam class tersebut ialah hukum nun bersukun, hukum mim bersukun, hukum idgham, hukum mim dan nun bertasdid, hukum idgham, hukum lam tarif, hukum qalqalah dan hukum mad.

c. Class latihan, merupakan class yang menampilkan soal latihan yang akan dijawab oleh user.

d. Class info aplikasi, merupakan class yang menampilkan informasi aplikasi tersebut yang terdiri dari informasi kontak pengembang dan informasi tutorial penggunaan aplikasi.

\section{Flowchart Divide and Conquer}

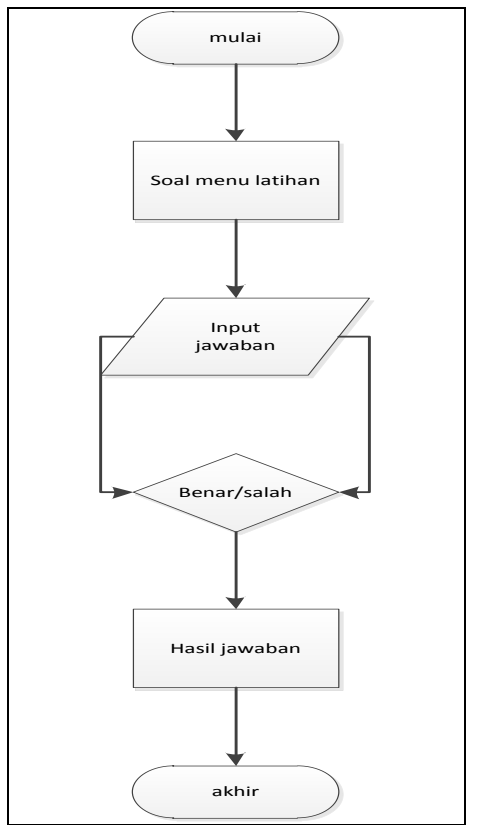

Gambar 4Flowchart Divide and Conquer

Gambar 4.3 merupakan flowchart divide and conquer, dimana user membuka soal menu latihan dan user memilih jawaban. Seteleh itu jawaban diproses dengan algoritma divide and conquer sehingga menghasilkan nilai yang diperoleh user setelah menjawab soal.

\section{Algoritma Divide and Conquer}

Pembuatan aplikasi belajar ilmu tajwid menggunakan algoritma divide and conquer yang diimplementasikan pada pencarian jawaban yang benar pada menu latihan aplikasi belajar ilmu tajwid. Berikut implementasi algoritma Divide and Conquer pada Aplikasi Belajar Ilmu Tajwid dijelaskan pada source code di bawah ini:

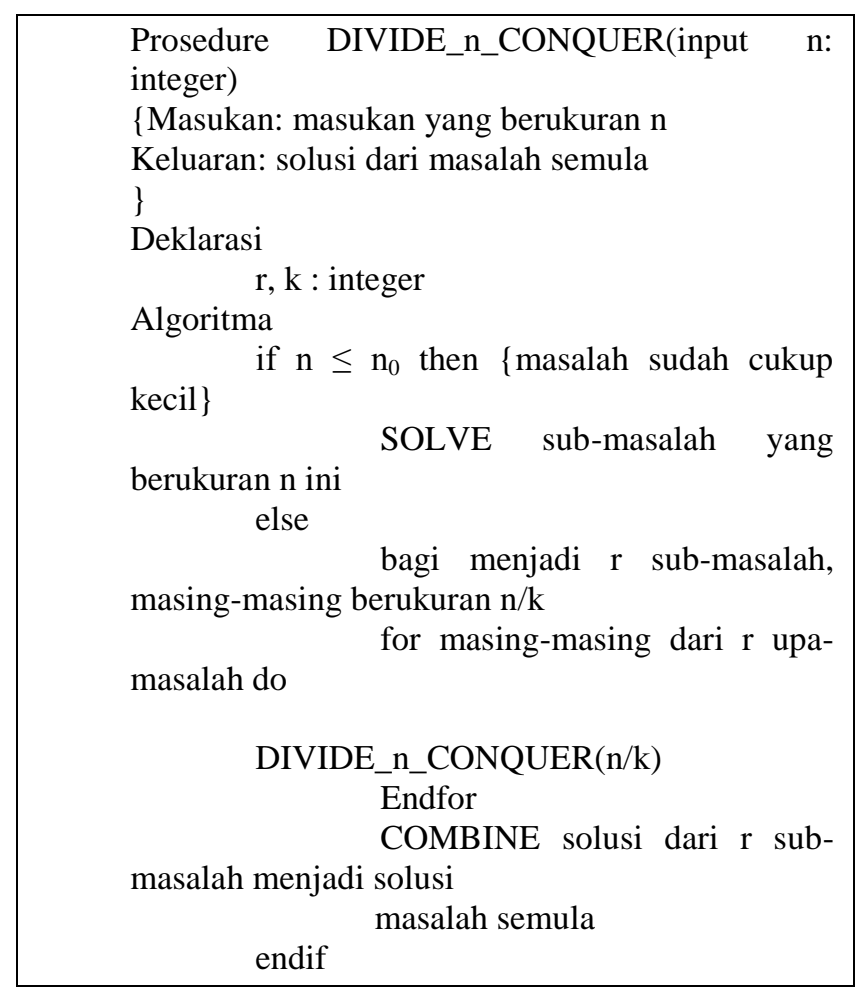


Contoh Algoritma Divide and Conquer:

Soal 1:<smiles>C#CC1CC1C#C</smiles>

jawaban $1=1$ jawaban2=2 jawaban $3=3$

Misal: jawaban yang dicari $=1$

\begin{tabular}{l|l|l|l|l|}
1 & 2 & 3 & Data Jawaban
\end{tabular}

Langkah-langkah penyelesaian:

a. Pada Array diatas terdapat barisan array yang terdiri dari 1, 2 dan 3. Bagi barisan array diatas menjadi 2 bagian dan hitung nilai tengahnya. Karena barisan array diatas terdiri dari 3 array, maka nilai tengah terdapat pada array ke-1 yaitu 2.

b. Setelah mengetahui nilai tengah dari barisan array maka bandingkan nilai tengah dengan data jawaban yang dicari. Jika nilai tengah sama dengan data yang dicari maka jawaban ditemukan dan pencarian data jawaban berhenti. Akan tetapi, jika nilai tengah lebih besar daripada data jawaban yang dicari maka pencarian jawaban dilakukan kesebelah kiri. Sebaliknya, jika nilai tengah lebih kecil daripada data jawaban yang dicari maka pencarian selanjutnya dilakukan kesebelah kanan.

c. Nilai tengah dari array diatas ialah 2 dan data jawaban yang dicari ialah 1, maka setelah dibandingkan maka nilai tengah $>$ data jawaban $\rightarrow 2>1$. Pencarian dilakukan kesebelah kiri karena nilai tengah lebih besar dari pada data jawaban yang dicari.

d. Data yang terdapat pada barisan array sebelah kiri atau array ke-0 ialah 1, maka setelah dibandingkan array ke-0 sama dengan data jawaban yang dicari. Maka pencarian berhenti dan jawaban ditemukan.

\section{E. Implementasi Antarmuka}

\section{Tampilan Menu Utama}

Gambar 4.1 merupakan tampilan utama aplikasi belajar ilmu tajwid. Dalam menu utama ini terdapat tiga button yaitu belajar, latihan dan info.

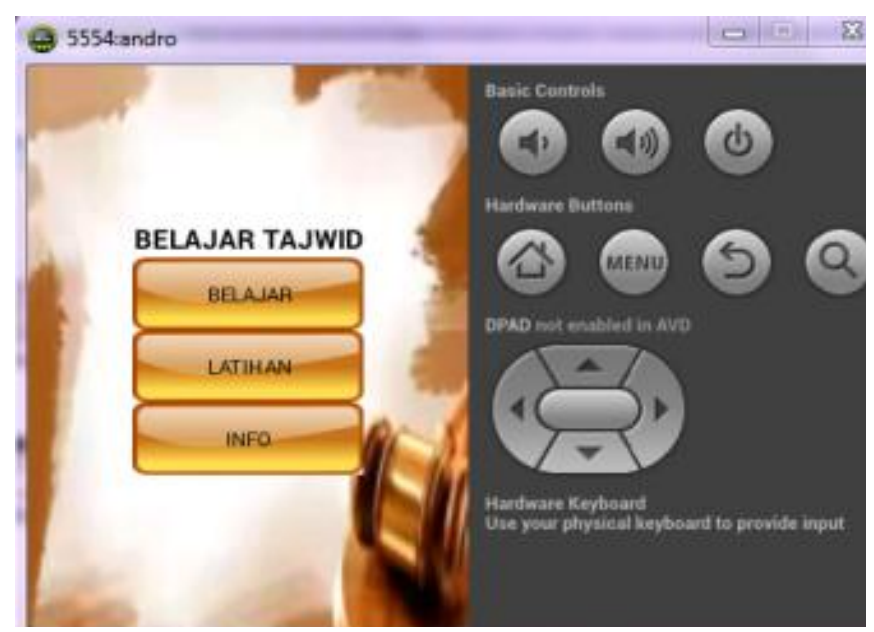

Gambar 5 Menu Utama Ilmu Tajwid

2. Tampilan Menu Belajar
Pada menu belajar ini terdapat beberapa button yaitu hukum nun bersukun, hukum mim bersukun, hukum idgham, hukum lam ta'rif, hukum qalqalah, hukum madd dan hukum mim dan nu bertasdid. Dalam setiap button itu berisi teori mengenai ilmu tajwid.

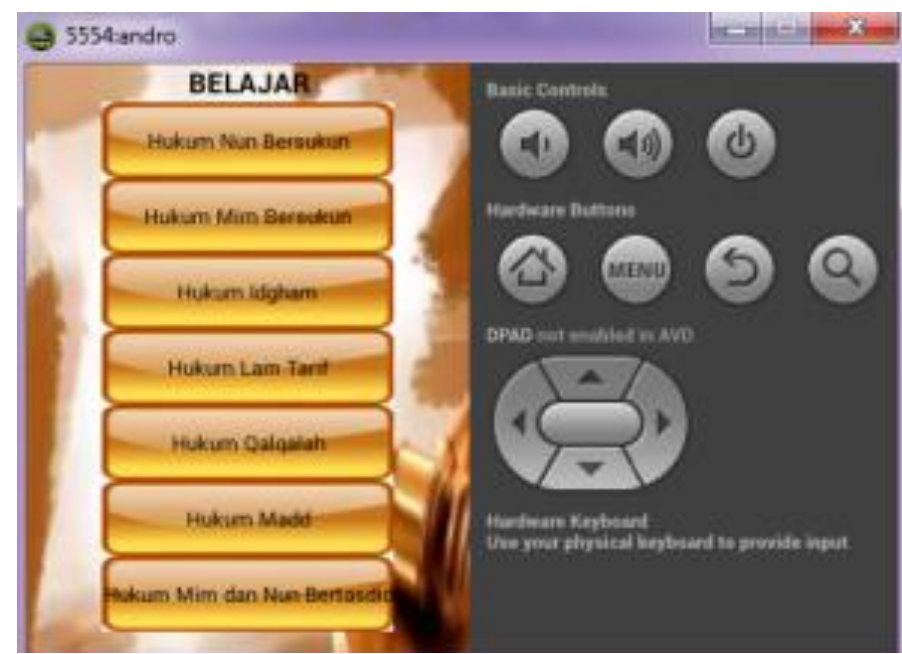

Gambar 6 Menu Belajar Ilmu Tajwid

\section{Tampilan Menu Latihan}

Pada menu latihan terdapat soal yang bisa dijawab oleh user. Dalam soal tersebut terdapat beberapa soal hukum bacaan yang akan dijawab user. Setelah user selesai menjawab soal maka sistem akan menampilkan jumlah jawaban yang salah dan benar.

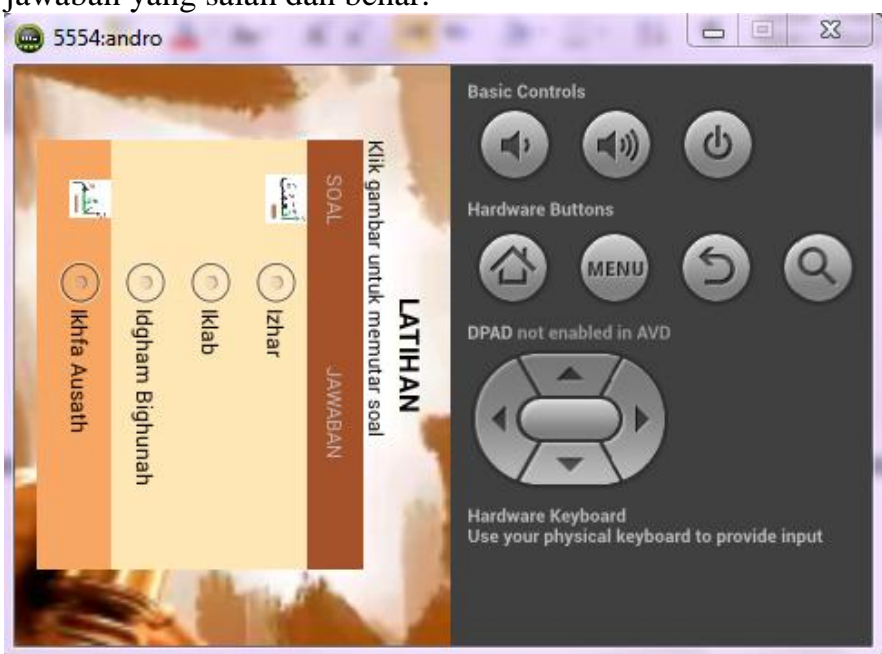

4. Tampilan Menu Info

\section{Gambar 7 Menu Latihan}

Dalam menu info ini terdapat tutorial penggunaan aplikasi dan informasi dari kontak pengembang. 


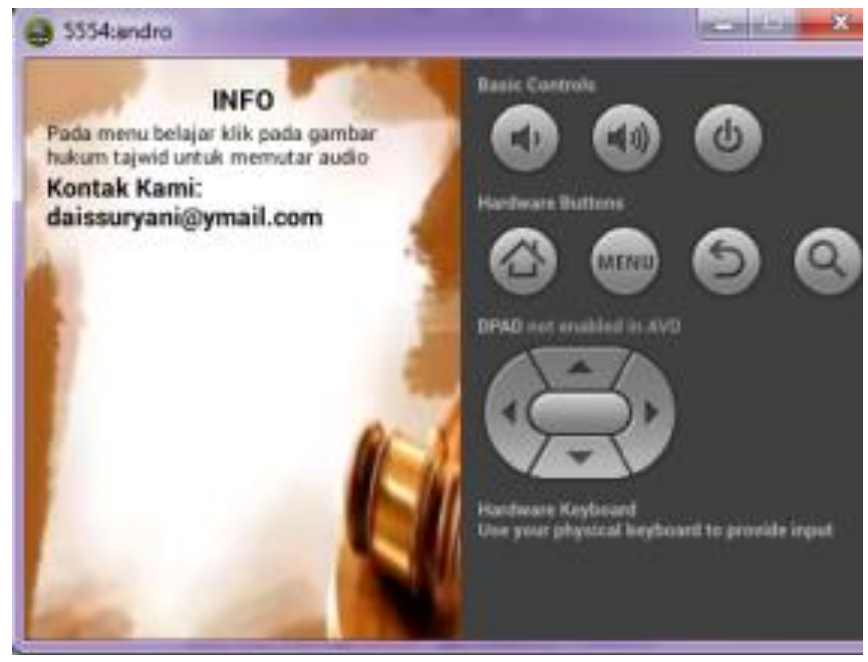

Gambar 8Menu Info

5. Kompleksitas Algoritma Divide and Conquer

Perbandingan waktu pencarian jawaban pada soal latihan dapat dilihat pada Tabel 5.1.

Tabel 1Perbandingan Waktu Pencarian Jawaban

\begin{tabular}{|c|c|c|c|c|}
\hline No & $\begin{array}{l}\text { Data } \\
\text { masukan }\end{array}$ & $\begin{array}{l}\text { Data } \\
\text { yang } \\
\text { dicari }\end{array}$ & $\begin{array}{l}\text { Algoritma } \\
\text { Divide and } \\
\text { Conquer }\end{array}$ & $\begin{array}{l}\text { Algoritma } \\
\text { Brute } \\
\text { Force }\end{array}$ \\
\hline 1 & $1,2,3$ & 1 & $\begin{array}{l}2,86 \\
\text { second }\end{array}$ & 6 second \\
\hline 2 & $1,2,3$ & 3 & $\begin{array}{l}2,86 \\
\text { second }\end{array}$ & 6 second \\
\hline 3 & $1,2,3$ & 3 & $\begin{array}{l}2,86 \\
\text { second }\end{array}$ & 6 second \\
\hline 4 & $1,2,3$ & 2 & $\begin{array}{l}2,86 \\
\text { second }\end{array}$ & 6 second \\
\hline 5 & $1,2,3$ & 3 & $\begin{array}{l}2,86 \\
\text { second }\end{array}$ & 6 second \\
\hline 6 & $1,2,3$ & 1 & $\begin{array}{l}2,86 \\
\text { second }\end{array}$ & 6 second \\
\hline 7 & $1,2,3$ & 2 & $\begin{array}{l}2,86 \\
\text { second }\end{array}$ & 6 second \\
\hline 8 & $1,2,3$ & 1 & $\begin{array}{l}2,86 \\
\text { second }\end{array}$ & 6 second \\
\hline 9 & $1,2,3$ & 2 & $\begin{array}{l}2,86 \\
\text { second }\end{array}$ & 6 second \\
\hline 10 & $1,2,3$ & 2 & $\begin{array}{l}2,86 \\
\text { second }\end{array}$ & 6 second \\
\hline 11 & $1,2,3$ & 3 & $\begin{array}{l}2,86 \\
\text { second }\end{array}$ & 6 second \\
\hline 12 & $1,2,3$ & 2 & $\begin{array}{l}2,86 \\
\text { second }\end{array}$ & 6 second \\
\hline 13 & $1,2,3$ & 1 & $\begin{array}{l}2,86 \\
\text { second }\end{array}$ & 6 second \\
\hline 14 & $1,2,3$ & 2 & 2,86 & 6 second \\
\hline
\end{tabular}

\begin{tabular}{|l|l|l|l|l|}
\hline No & $\begin{array}{l}\text { Data } \\
\text { masukan }\end{array}$ & $\begin{array}{l}\text { Data } \\
\text { yang } \\
\text { dicari }\end{array}$ & $\begin{array}{l}\text { Algoritma } \\
\text { Divide and } \\
\text { Conquer }\end{array}$ & $\begin{array}{l}\text { Algoritma } \\
\text { Brute } \\
\text { Force }\end{array}$ \\
\hline 15 & $1,2,3$ & 3 & $\begin{array}{l}2,86 \\
\text { second }\end{array}$ & 6 second \\
\hline 16 & $1,2,3$ & 2 & $\begin{array}{l}2,86 \\
\text { second }\end{array}$ & 6 second \\
\hline 17 & $1,2,3$ & 1 & $\begin{array}{l}2,86 \\
\text { second }\end{array}$ & 6 second \\
\hline 18 & $1,2,3$ & 2 & $\begin{array}{l}2,86 \\
\text { second }\end{array}$ & 6 second \\
\hline 19 & $1,2,3$ & 3 & $\begin{array}{l}2,86 \\
\text { second }\end{array}$ & 6 second \\
\hline 20 & $1,2,3$ & 1 & $\begin{array}{l}2,86 \\
\text { second }\end{array}$ & 6 second \\
\hline
\end{tabular}

Divide and Conquer $=O(n \log n)$

Brute Force

$$
\begin{aligned}
& =2(3 \log 3) \\
& =2,86 \text { second }
\end{aligned}
$$$$
=\mathrm{O}(\mathrm{n})
$$$$
=2(3
$$$$
=6 \text { second }
$$

\section{KESIMPULAN DAN SARAN}

\section{A. Kesimpulan}

Kesimpulan yang dapat diambil dari Tugas Akhir yang berjudul "Implementasi Algoritma Divide and Conquer Pada Aplikasi Belajar Ilmu Tajwid" ini yaitu:

a. Aplikasi belajar ilmu tajwid yang dibangun mengimplementasikan algoritma divide and conquer yang diterapkan pada pencarian jawaban yang ada pada soal latihan dengan kecepatan pencarian 2,86 second sesuai dengan Tabel 4.7.

b. Aplikasi belajar ilmu tajwid yang dibangun dapat membantu user membaca Al-Quran dengan fasih sesuai dengan tajwidnya karena pada aplikasi terdapat contoh hukum tajwid beserta audio sehingga user dapat mengetahui makna panjang pendek suatu bacaan Al-Quran.

c. Aplikasi yang dibangun membantu user belajar tajwid dimana saja karena aplikasi yang dibangun bersifat mobile yang dapat mendukung proses pembelajaran menggunakan teks dan suara.

\section{B. Saran}

Dalam pembangunan aplikasi belajar ilmu tajwid ini masih jauh dari sempurna, maka perlu dilakukan pengembangan dan penyempurnaan lebih lanjut. Adapun saran agar aplikasi bisa berfungsi dengan lebih optimal yaitu:

a. Penambahan teori mengenai makhraj huruf sehingga pengucapan ayat Al-Quran bisa sesuai makhrajnya.

b. Penambahan teori tentang waqaf sehingga user dapat mengetahui tentang pemberhentian bacaan ayat AlQuran. 
c. Penambahan teori mengenai makhraj huruf sehingga pengucapan ayat Al-Quran bisa sesuai makhrajnya.

d. Penambahan teori tentang waqaf sehingga user dapat mengetahui tentang pemberhentian bacaan ayat AlQuran.

e. Penambahan soal latihan yang random tentang tajwid sehingga user dapat menjawab soal dengan urutan yang berbeda.

f. Pembuatan aplikasi berbasis web sehingga user dapat belajar tajwid dan saling berbagi ilmu tajwid dengan user lain tanpa dibatasi jenis device.

g. Perngembangan aplikasi hingga tahap mengetahui perkembangan pengetahuan user seputar ilmu tajwid.

\section{DAFTAR PUSTAKA}

[1] Kadir, Abdul. 2013. From Zero to a Pro Pemrograman Android. Yogyakarta: Andi. [2]prihastomo.files, wordpress.com/2008/01/divideconquer. pdf diakses tanggal 09 April 2015 Pukul 05:09 WIB

[3] Abdurohim, Acep Iim. 2013. Pedoman Ilmu Tajwid Lengkap. Bandung: Diponegoro.

[4] Pressman, Roger. 2010. Rekayasa Perangkat Lunak. Yogyakarta: Andi.

[5] Safaat, Nazaruddin. 2014. Pemrograman Aplikasi Mobile Smartphone dan Tablet PC Berbasis Android. Bandung: Informatika.

[6] Huda, Arif Akbarul,. 2013. Live Coding! 9 Aplikasi Android Buatan Sendiri. Yogyakarta: Andi.

[7] Munawar. 2015. Pemodelan Visual dengan UML. Yogyakarta: Graha Ilmu. 